\title{
obituary
}

\section{William Linford Llewelyn Rees}

\author{
Formerly President of the \\ Royal College of \\ Psychiatrists (1975-1978)
}

Sitting in a meeting of the Welsh Psychiatric Society a few years ago, I was surprised to see a familiar, but now infirm, figure being helped to the front row by family and friends. I wondered how many of the juniors in the room would know that this was Linford Rees, one of the founding fathers of modern British psychiatry, still nourishing his Welsh roots as he approached his 90th year. Then, having listened carefully to the speaker, he asked the most incisive question of the day - and everyone knew that we were in the presence of wisdom.

Linford Rees died on 29 July at the age of 89; with him went a life story of medical achievement that began and ended with Wales and touched every part of the psychiatric world in between. Linford was the eldest son of Edward Parry Rees and Mary Rees of Llanelli, Carmarthenshire. He was educated at Llanelli Grammar School and the University College, Cardiff, Welsh National School of Medicine. He went on to the Maudsley Hospital and University of London (BSC 1935; MB BCh 1938), picking up the David Hepburn Medal/Alfred Hughes Medal in Anatomy, and John McLean Medal/Prize in Obstetrics and Gynaecology along the way.

His early career saw him working as Deputy Medical Superintendent of Mill Hill Emergency Hospital (1945), Assistant Physician and Postgraduate Teacher in Clinical Psychiatry at the Maudsley (1946), Deputy Physician Superintendent of Whitchurch Hospital, Cardiff (1947) and Regional Psychiatrist for Wales and Monmouthshire, which at that time did not quite know to which country it belonged (1948). He went on to become Consultant Physician at the Bethlem Royal and Maudsley (1954-66), Clinical Teacher in Mental Diseases at the Institute of Psychiatry (1956-78) and Lecturer in Psychological Medicine at St Bartholomew's Medical College (1958-78). He ended, of course, as Professor of Psychiatry in the University of London and as a Governor of that most holy of trinities - the Bethlem Royal and Maudsley, St Bartholomew's (1980-96) and University College, Cardiff (1984). He was awarded the CBE in 1978.

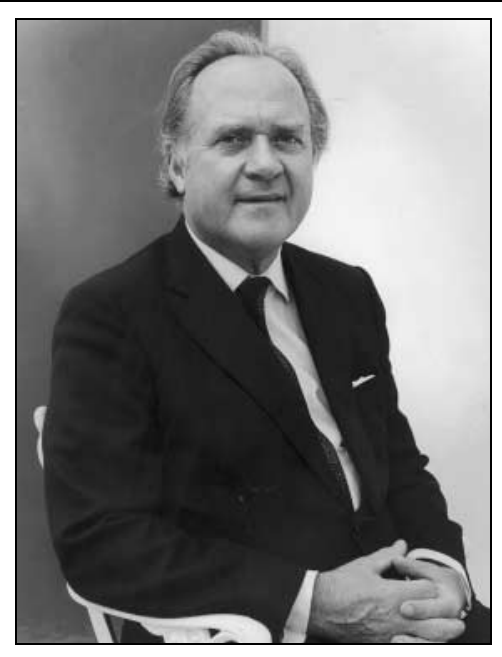

Linford's name will always be associated with the very beginnings of our College. He was a leading light in the Council of the old Royal Medico-Psychological Association in the late 1950s and early 1960s and a founding Fellow of the Royal College of Psychiatrists at its inception in 1971. He was the College's first VicePresident (1972-75) and its second President (1975-78), succeeding Sir Martin Roth. He was made an Honorary Fellow to the College, its highest gift, in 1978 and was part of the Conference of Presidents of Royal Colleges - the forerunner of the present Academy. It is extraordinary to think that Linford was writing on the dimensions of personality with Eysenck and Himmelweit in 1947 and still had the energy to produce a textbook of psychiatry half a century later! Between times, he contributed chapters on everything from general practice to psychoendocrinology as well as papers to all the reputable journals. He was joint editor of the Journal of Psychosomatic Research, and an examiner for the College and many other institutions.

But Linford's influence went much further than this, both in subject and in geography. At home, he was President of the British Medical Association (1978-79), Chairman of the Medico-Pharmaceutical Forum (1982) and a leading member of the Education Committee, Preliminary Health Committee and Professional Conduct Committee of the General Medical Council (1980-84). He sat on the Committee on Safety of Medicines, the Asthma Research Council, the Central Health Services Council, and on the executive bodies of the Stress Syndrome Foundation, the Society for the Study of Human Biology and innumerable committees within the University of London.

Abroad, Linford was a tireless lecturer to universities throughout Europe, Asia, Australia, the USA and South America. He was Treasurer of the World Psychiatric Association (1966), a founder member of the International College of Neuropsychopharmacology and Vice-President of the International College of Psychosomatic Medicine (1973). He was an honorary member of learned societies in many countries, a Distinguished Fellow of the American Psychiatric Association (1968), and an Honorary Fellow of the American Society of Physician Analysts, the American College of Psychiatrists, the Biological Psychiatry Association, USA, and the Hong Kong Psychiatric Society. He was a World Health Organization Consultant to Sri Lanka in 1973.

It is difficult to know how he found either the time or strength, but well into his 70s, Linford was acting as Chief Psychiatrist and Executive Medical Director of Charter Medical (1984-89). He was Director and Medical Advisor to Huntercombe Manor (1989) and Consultant Advisor to Ultramind (1996). He was Chairman of the Armed Services Consultant Advisory Board in Psychiatry (197990) and a Consultant Advisor to such widely different bodies as the RAF and the Royal School for Deaf Children. It must have been with great honour but some light relief that he was made a liveryman by both the Barber Surgeons and the Apothecaries.

Above all, throughout this distinguished achievement, Linford remained a family man. He was married for over 50 years, until her death in 1993, to Catherine herself from Glamorgan in South Wales. Their two sons and two daughters became familiar figures around the College. Angharad, who lives just round the corner, brought her father each year to the Dinner for Honorary Fellows, undeterred by age and the College lift. Not surprisingly, he listed his favourite occupation as 'amusing grandchildren' and, no doubt, his great-grandchildren too.

And Wales always seemed part of that family. I am not sure if Linford was the only President with an Honorary LLD from Wales (1981), but he was certainly the only President who was a Bard of the Welsh Gorsedd.

"Diolch, Linford. 'Roeddwn yn dy garu ac edmygu. Gorffwysa mewn hedd."

Mike Shooter President of the Royal College of Psychiatrists 